Abstracta Iranica Abstracta Iranica

Revue bibliographique pour le domaine irano-aryen

Volume 25 | 2004

Comptes rendus des publications de 2002

Musique des Oügours. Tradition d'Ili et de Kashgar. CD
avec livret de présentation, (français et anglais),
Paris, Maison des Cultures du Monde, 2002.

Rédaction

(2) OpenEdition

Journals

Édition électronique

URL : http://journals.openedition.org/abstractairanica/5273

DOI : 10.4000/abstractairanica.5273

ISSN : 1961-960X

Éditeur :

CNRS (UMR 7528 Mondes iraniens et indiens), Éditions de l'IFRI

Édition imprimée

Date de publication : 15 mai 2004

ISSN : 0240-8910

Référence électronique

Rédaction, « Musique des Ouïgours. Tradition d'lli et de Kashgar. CD avec livret de présentation, (français et anglais), Paris, Maison des Cultures du Monde, 2002. », Abstracta Iranica [En ligne], Volume 25 | 2004, document 372, mis en ligne le 15 mars 2006, consulté le 25 septembre 2020. URL : http:// journals.openedition.org/abstractairanica/5273 ; DOI : https://doi.org/10.4000/abstractairanica.5273

Ce document a été généré automatiquement le 25 septembre 2020.

Tous droits réservés 


\section{Musique des Ouïgours. Tradition d'Ili et de Kashgar. CD avec livret de présentation, (français et anglais), Paris, Maison des Cultures du Monde, 2002.}

\section{Rédaction}

Enregistré au cours de deux concerts préparés par l'auteur et donnés à la Maison des Cultures du Monde, ce CD se présente comme un bref panorama de la musique mal connue des Ouigours, interprété par des artistes venant de Chine populaire ainsi que de la diaspora d'Asie centrale. La présentation, de caractère scientifique, cite et traduit les premiers beyt de chaque chant.

\section{INDEX}

Thèmes : 17.1.Musique

\section{AUTEURS}

\section{RÉDACTION}

Directeur de la revue et secrétariats (Paris et Téhéran) 